\title{
Recent advances in potentiometric biosensors
}

\author{
Jiawang Ding a, b, c, *, Wei Qin a, b, c, ** \\ a CAS Key Laboratory of Coastal Environmental Processes and Ecological Remediation, Yantai Institute of Coastal Zone Research (YIC), Chinese Academy of \\ Sciences(CAS), Shandong Key Laboratory of Coastal Environmental Processes, YICCAS, Yantai, Shandong 264003, PR China \\ ${ }^{\mathrm{b}}$ Laboratory for Marine Biology and Biotechnology, Pilot National Laboratory for Marine Science and Technology (Qingdao), Shandong 266237, PR China \\ ${ }^{\mathrm{c}}$ Center for Ocean Mega-Science, Chinese Academy of Sciences, Qingdao, Shandong, 266071, PR China
}

\section{A R T I C L E I N F O}

\section{Article history:}

Available online 3 January 2020

\section{Keywords:}

Potentiometry

Ion-selective electrode

Potentiometric biosensing

Bioreceptor

Biosensor

\begin{abstract}
A B S T R A C T
Potentiometry based on ion-selective electrodes (ISEs) has been injected with new vigor and gone through a renaissance with the improvements in the detection limits and selectivities of ISEs, the introduction of new materials, new sensing concepts (from conventional potentiometry to dynamic electrochemistry approaches), and deeper theoretical understanding and modelling of the potentiometric responses of ISEs. The new breakthroughs encourage innovations in ion sensing and biosensing applications. Moreover, with the introduction of new bioreceptors, such as enzymes, antibodies, aptamers, peptides, versatile sensing protocols have been designed for a broad range of different target molecules by using ISEs as powerful transducers. This paper reviews the recent trends in potentiometric biosensors. Their applications in biosensing of metal ions, small molecules, DNA, proteins, bacteria and toxicities have been discussed. This review provides the outlook of the potentiometric biosensing based on the integration of potentiometric ISEs with new materials and emerging techniques.
\end{abstract}

(c) 2020 Elsevier B.V. All rights reserved.

\section{Introduction}

Biosensing technologies are of increasing importance in the fields of healthcare, industrial process control, environmental monitoring, and military applications. Therefore, considerable efforts have been devoted to the development of versatile, sensitive and selective biosensing systems for various targets, using electrochemical, optical, and mass-sensitive transduction modes. Electrochemical detection techniques include amperometric, potentiometric, impedimetric and conductometric methods [1,2].

Potentiometry based on polymeric membrane ion-selective electrodes (ISEs) is a well-established analytical technology that has been routinely applied for physiological testing of key electrolytes [3-6]. Potentiometric sensors show advantages of small size, rapid response, ease of use, low cost and resistant to color and

\footnotetext{
* Corresponding author. CAS Key Laboratory of Coastal Environmental Processes and Ecological Remediation, Yantai Institute of Coastal Zone Research (YIC), Chinese Academy of Sciences(CAS), Shandong Key Laboratory of Coastal Environmental Processes, YICCAS, Yantai, Shandong 264003, PR China.

** Corresponding author. CAS Key Laboratory of Coastal Environmental Processes and Ecological Remediation, Yantai Institute of Coastal Zone Research (YIC), Chinese Academy of Sciences(CAS), Shandong Key Laboratory of Coastal Environmental Processes, YICCAS, Yantai, Shandong 264003, PR China.

E-mail addresses: jwding@yic.ac.cn (J. Ding), wqin@yic.ac.cn (W. Qin).
}

turbid interferences. Moreover, ISEs have some unique features. They provide information about the free ion concentration (ion activity), which is different from other analytical methods that give the total concentration. They are, at least in principle, independent of the sample volume, so that the drastical decrease in sample volume does not deteriorate the detection limits. These properties make ISEs truly unique as an indicator electrode or a detector.

Since the discovery of ion fluxes across the polymeric membrane of ISEs in 1990s, ISEs have been injected with new vigor and undergone a quiet revolution in the last 20 years. Remarkable achievements in ISEs have been attained, including low detection limit ISEs, polyion sensors, solid-contact ISEs, and new sensing concepts for dynamic potentiometry. In parallel, promising models and numerical simulation for mechanisms were proposed. Since the pioneering work on lower detection limit ISEs introduced by the group of Pretsch [7], the lower detection limit and the selectivity coefficients have been improved in many cases by factors up to $10^{6}$ and $10^{10}$, respectively [5]. Potentiometry at trace levels in confined samples have placed potentiometry among the most sensitive electrochemical methods available [8]. After the discovery of the polyion-selective electrode by the groups of Meyerhoff and Yang [9-11], significant progresses have been made in elucidating the response mechanism and their applications for detection of highly charged macromolecules in biological sample. By introducing conducting polymers and nanomaterials, solid-contact ISEs 
with improved potential stabilities and sensitivities and with free calibration have been envisioned as a promising and reliable tool for practical applications in view of their advantages in robustness, free maintenance and miniaturization [12-18]. Meanwhile, solidstate reference electrodes have been rationally designed and manufactured [19-23]. Currently, several groups including the Bühlmann [24], Bobacka [25], Bakker [26], Lindner [27], Gyurcsányi [28], Qin [29], Lindfors [30], Crespo [31], and Michalska [32] group are active in this field. Recently, the introduction of nanopore show promises for potentiometric sensing applications [33-35].

More importantly, attractive dynamic electrochemistry approaches including chronopotentiometry [36,37], controlled reagent release [38,39], coulometric analysis [40-42], have been introduced by Bakker's group and widely adopted by researchers to establish attractive methodologies [43,44]. New ion-selective readout principles based on chronopotential [45], transition time [46], charge of transient current pulse [47,48], voltammetric current [49,50], optical signal [51-53] have been proposed, which makes the calibration-free sensors possible [54].

Recent years have seen the new applications of ISEs for point-ofcare diagnostics and on-site environmental analysis by using a disposable or flexible diagnostic device [55-57]. By using the tattoo-based platform and tailor-made stretchable materials, Wang's group have designed a number of tattoo-based potentiometric ion-selective sensors and wearable multi-ion potentiometric sensor [58]. Recently, wireless sensor networks such as remote environmental monitoring and wearable sensors or body sensor networks gain popularity. The integration of different kind of ISEs with wearable sensor arrays represents a next-generation platform for healthcare, diagnostics and environmental monitoring [59]. Moreover, handheld device that couples the sensors including potentiometry directly to "the cloud" using any mobile phone can be a good option for resource-limited areas [60]. Nowadays, researchers have established potentiometry based on ISE as an important, modern technique to detect targets ranging from ionic species to neutral species, from small molecules to biomolecules.

With the new breakthroughs in ISEs [61,62], potentiometry has been deemed as a powerful transducer for biosensing. In this review, advances in potentiometric biosensor during the period between 2011 and 2019 are summarized. Ion-sensitive field-effect transistors (ISFETs) and light-addressable potentiometric sensors are beyond the scope of the present review. It should be noted that biosensors based on biologically coupled ISFETs have been advanced a lot and made important contributions to the field of potentiometric biosensing [63]. For example, pH-sensitive ISFETs were designed to directly perform DNA sequencing of genomes $[64,65]$ and detect antigen-antibody reactions [66]. The present review summarizes recent progresses in the applications of potentiometric biosensing with a special emphasis on the use of polymeric membrane ISEs. The applications of ISEs for potentiometric sensing of metal ions, small molecules, DNA, enzymes, proteins, bacteria cells and toxicities are demonstrated (see Fig. 1). The outlook of the potentiometric biosensing based on the integration of potentiometric ISEs with new materials and emerging techniques is also shown.

\section{Potentiometric biosensors}

Up to now, potentiometry has become the standard technique in the clinical analysis of ions, particularly the determination of the biologically relevant electrolytes in physiological fluids or even in cells such as $\mathrm{Na}^{+}, \mathrm{K}^{+}, \mathrm{Ca}^{2+}$, and $\mathrm{Cl}^{-1}[3,4,67]$. For example, coupled with a miniaturized wearable wireless transceiver, Wang's group developed a tattoo-based potentiometric sensor for real-time

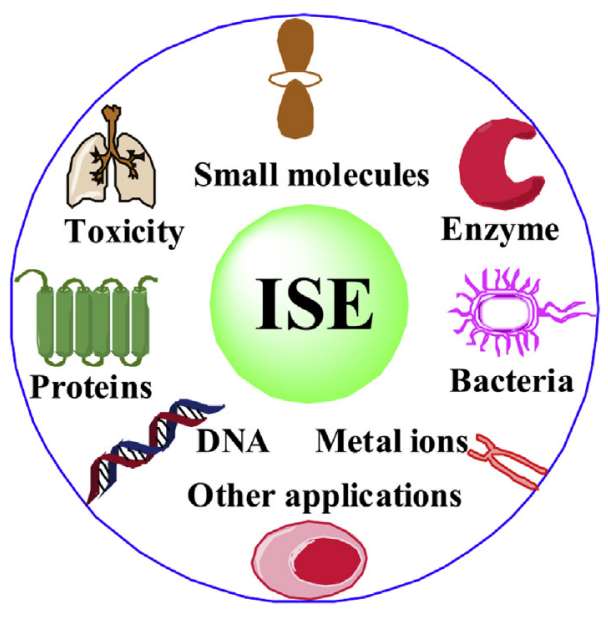

Fig. 1. Schematic illustration applications of ion-selective electrodes for potentiometric detection of various targets.

monitoring in human perspiration [68]. The potentiometric sensors for electrolytes are now considered mature products by many companies. However, their further developments for other targets are promising. In this review, we will focus on the potentiometric biosensing based on the use of the bioreceptor such as enzymes, antibodies, aptamers, peptides or even whole cells. In the following sections, we summarize the applications of potentiometric biosensors for detection of metal ions, small molecules, DNA, enzymes/proteins, bacteria cells and toxicities.

\subsection{Metal ions}

It is a challenge to incorporate the biological materials into poly(vinyl chloride) (PVC) membranes due to the use of organic solvents, into which protein macromolecules can be poorly dissolved and hardly retain their activities. Polysulfone, a porous and biocompatible polymer that can incorporate the biological materials to the membrane during a phase inversion process, was used to design an $\mathrm{Ag}^{+}$-ISEs embedding metallothioneins as ionophores [69]. However, because of the unavailability of biomolecules for specific metal ions, the applications of this method are limited. Peptide nanofibrils were used as biorecognition elements for complexation with copper ions [70]. These self-assembled peptide nanofibrils allow selective detection of metal ions by tuning the peptide sequence to interact with a specific metal ion. Very recently, Gyurcsányi's group proposed a promising and general concept based on hydrophilic ionophore-modified nanopores. By using a nanoporous membrane as solid support, hydrophilic ligands such as metal binding peptides were used to construct ISEs (Fig. 2A) [71]. In addition, some metal ions can selectively bind to native or artificial bases in DNA duplexes to form metal-mediated base pairs. For example, silver ions can selectively coordinate cytosine (C) bases, while $\mathrm{Hg}^{2+}$ is shown to specifically bridge thymine (T) bases (Fig. 2B, C). The probes contain mismatched bases were used as host molecules for potentiometric biosensing of ions [72]. Moreover, metal specific DNAzymes including DNAzymes for $\mathrm{Pb}^{2+}, \mathrm{Cu}^{2+}$, and $\mathrm{Zn}^{2+}$ were selected and used as a potential platform for sensing a wide range of metal ions [73]. These DNAzymes can be used as bioreceptors for potentiometric sensing of metal ions with high selectivities (as shown in Fig. 2D).

As an alternative, metal ions can be indirectly sensed based on the enzyme inhibition principle. For example, mercury can be indirectly determined by a potentiometric glucose biosensor based on the inhibition of the glucose oxidase [74]. Based on a similar 
A

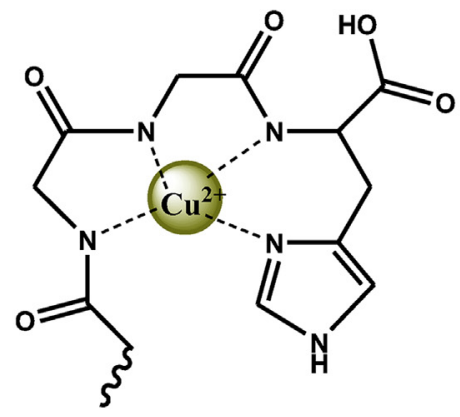

B
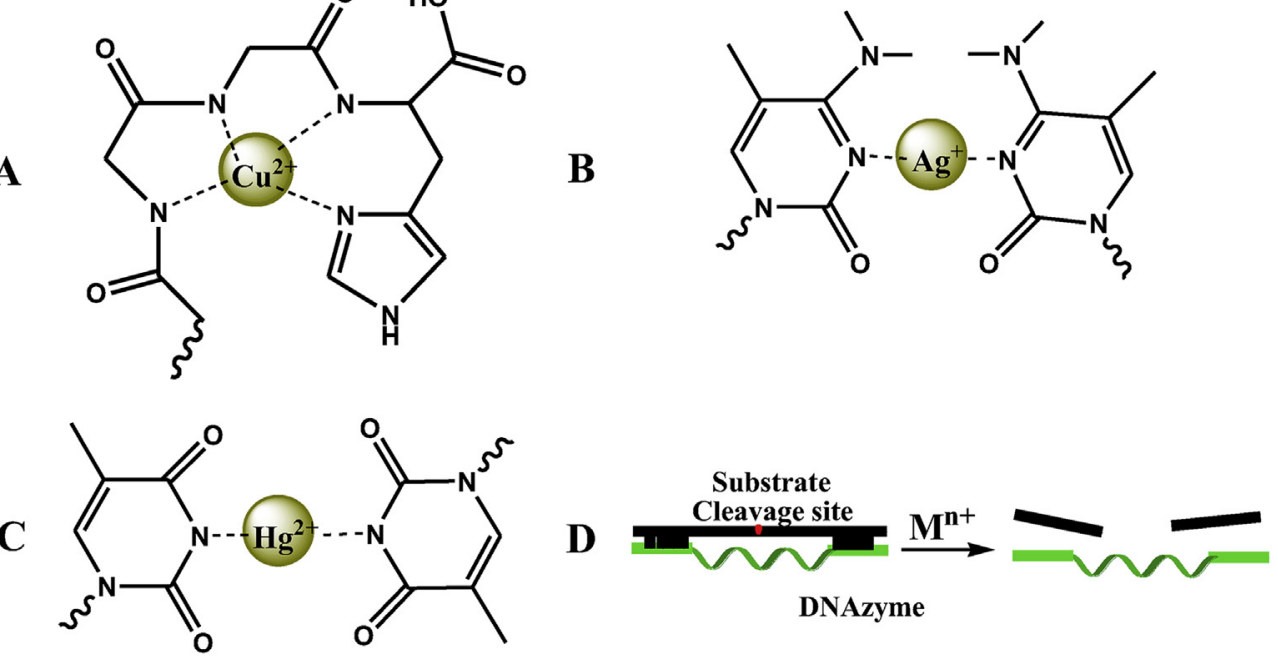

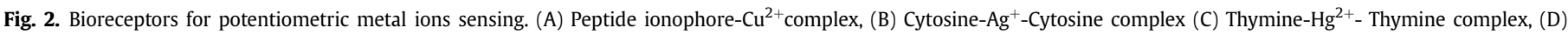
metal ions specific DNAzymes.

sensing protocol, whole cell microbial biosensors can be developed for rapid, on-site heavy metal ions detection. These biosensors were developed as a means for detection of a range of heavy metals with increased specificities and sensitivities based on a synthetic biology approach [75].

\subsection{Small molecules}

For many small molecules, an ionophore with high selectivity over discriminated ions is unavailable. Alternative strategies, including analyte-induced enzymatic reactions or inhibition of enzyme activities, immunoassays based on antibodies or aptamers, have been developed to detect small molecules.

Up to now, many small molecules involved in an enzymatic reaction can be sensed potentiometrically using an enzyme electrode. Various matrixes and schemes for enzyme immobilization have been developed. Among all these matrixes, zinc oxide ( $\mathrm{ZnO})$ nanostructures which possess unique features such as non-toxicity, biocompatibility, high electron-transfer rate and easy preparation, have attracted considerable interest in the applications of potentiometric biosensors [76]. As a suitable matrix for enzyme immobilization, zinc oxides have been modified with enzymes for potentiometric detection of a large number of small molecules including cholesterol [77,78], galactose [79], L-lactic acid [80], uric acid [81] and so on. For these protocols, the enzyme reactions can lead to the changes in ionic distribution around the $\mathrm{ZnO}$ nanostructures, resulting in potential responses of the electrode. Without enzyme immobilization, small molecules can also be detected based on two different approaches. In one protocol, the target molecule, as an enzyme substrate, can be directly or indirectly measured by detecting ions generated by an enzymatic reaction. Creatinine [82], urea [83], glucose [84,85], glutamate [86], permethrin [87] were detected based on this sensing principle. Recently, bacterium Klebsiella sp. MP-6 which was isolated from long-term organophosphorus pesticide contaminated soils, is capable of biodegrading methyl parathion to produce $p$-nitrophenol. The $p$-nitrophenol can be deprotonated under basic conditions and thus detected by using the anion exchanger based membrane electrode [88]. In the other protocol, the target works as an inhibitor to the enzyme. By measuring the enzyme activity, the small molecule can be indirectly detected [89]. For example, organophosphate pesticides are irreversible inhibitors of cholinesterases. Potentiometric biosensing strategy for the determination of organophosphate pesticides based on BuchE inhibition can be designed [90].

Immunoassays can be utilized to detect small molecules by applying the specific binding between antibodies-antigens. However, small molecules should be coupled to carrier proteins to obtain immunogenicity prior to immunization, which could restrict the wide applications. In recent years, aptamers, which are singlestranded DNA or RNA oligonucleotides selected in vitro to bind a variety of analytes ranging from small ions to large proteins with high specificities and affinities, have been emerged as an alternative bioreceptors in lieu of antibodies for biosensing [91]. The ability of an aptamer to translate a specific small molecule signal into the output of potentiometric signal enables the development of new, broadly applicable small-molecule sensing platforms. Nagels and coworkers fabricated an aptamer doped gelatin layer for potentiometric sensing of small molecule/biomolecule binding kinetics. Targetbinding induced surface potential was used as a signal [92]. By layer-by-layer assembling of carboxylated multiwall carbon nanotubes, poly(diallyldimethylammonium chloride) (polycation), and aptamer (polyanion) on an electrode surface, Qin's group designed a potentiometric aptasensor based on the target-binding induced variation of the surface charge (negative to positive). The introduction of polyions can cause substantial charge change on the electrode surface, thus improving the sensitivity of the sensor [93]. Ding et al. developed a label-free and substrate-free potentiometric platform to signal aptamer/target binding events [94]. Potentiometric titrations or the direct detection based on chronopotentiometry was developed for adenosine triphosphate (ATP). Although elegant, such a protamine-based detection strategy is restricted to aptamer/target couples able to induce sufficiently high conformational change, a condition that cannot be always easily achieved. As an alternative, the same group introduced a general, facile, and label-free potentiometric assay based on metal-mediated DNA base pairs for ATP [72]. In this protocol, a nucleic acid with the target binding sequence in the middle and cytosine-rich sequences at the lateral portions was designed. A target binding-induced aptamer conformational change prevents the formation of the metal-mediated DNA base pairs, thus changing the concentration of silver ions at the interface of silver ISEs, which can be sensed potentiometrically. Very recently, a sensitive and versatile potentiometric platform, which allows potentiometric sensing to be 
applied to any class of molecule, was demonstrated by Ding and his coworkers [95]. In this method, DNA nanostructures are selfassembled on magnetic beads via the incorporation of an aptamer into a hybridization chain reaction. The aptamer-bisphenol A binding event leads to the disassembly of the DNA nanostructures, which results in a dramatic change in the surface charge of the magnetic beads. Such a surface charge change can be sensitively detected by a polycation-sensitive membrane electrode using protamine as an indicator (Fig. 3). Considering the ability of aptamer to recognize various targets, the method is adaptable to facile detection of a wide range of targets. While potentiometric aptasensing of small molecules is extremely appealing due to its flexibility and versatility, the selection of aptamers with high binding affinities continue to be a challenge.

\subsection{DNA and microRNA}

There is a growing demand for the rapid and accurate detection of specific DNA sequences in various fields, including clinical diagnosis, forensic investigations and bacterium/virus identification. Electrochemical detection of DNA represents a very attractive approach for rapid, sensitive, and high-throughput DNA analysis. Nanoparticles are currently of great interest especially due to their usage for labels in bioanalytical applications. Nowadays, potentiometry based on ISEs can achieve trace (subfemtomole) measurements in very small (microliter) sample volumes [8]. By combining the high sensitivity of the potentiometry based on ISEs with the versatility of nanoparticles, highly sensitive potentiometric assays for DNA can be obtained. Many types of nanoparticles with different sizes and compositions facilitate potentiometric applications in DNA sensors [96-98] (As shown in Fig. 4). The proposed potentiometric detection route can be extended to highthroughput DNA analysis in connection with different nanoparticle tags as mentioned above. Note that the use of "green" calcium ion tracer instead of nanocrystals can decrease the contingent adsorption and/or complexation between biomolecules and released metal ions.

Enzyme tags can also be used to monitor the DNA hybridization events. It has been shown that highly-sensitive potentiometric sensing protocol for DNA can be designed based on alkaline phosphatase-induced biometallization [99]. Recently, both horseradish peroxidase (HRP) and alkaline phosphatase (ALP) were used as enzyme tags for designing a potentiometric genosensor based on magnetic beads-enzyme sandwich [100]. Interestingly, the positively charged reactive intermediates based on the $\mathrm{HRP}-\mathrm{H}_{2} \mathrm{O}_{2}$ oxidation reaction and the negatively charged products based on the ALP-catalyzed hydrolysis of substrate can be sensed sequentially on a single ISE. Under a series of periodic galvanostatic polarization, a solid-contact ISE without ion exchanger properties under zero-current conditions was successfully developed for

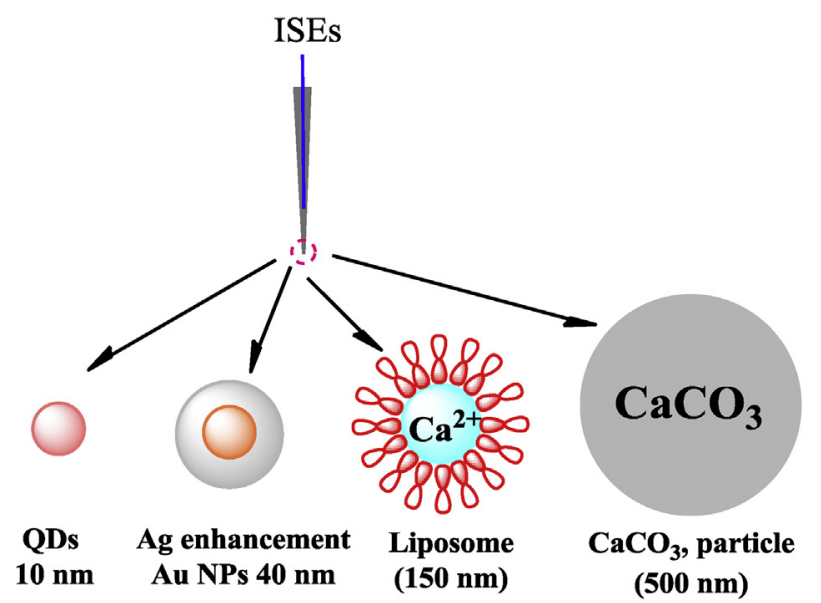

Fig. 4. Different particle labels used in potentiometric detection.

simultaneous, rapid, and specific quantitation of two specific DNA targets. DNAzymes have been widely applied as signal amplifiers for enzyme-free amplified detection of DNA. Qin's group found that the G-quadruplex/hemin DNAzyme-catalyzed oxidative coupling of monomeric phenols can induce large potential signals on quaternary ammonium salt-doped polymeric membrane electrodes. Two label-free potentiometric DNA assay protocols based on the Gquadruplex/hemin DNAzyme have been developed with sensitivities higher than those of colorimetric and fluorometric method [101,102].

As an alternative, intercalators for DNA have been used as reporters for label-free potentiometric DNA sensing. By coupling the amplification capability of the primer generation-rolling circle amplification with the intercalator of ethidium bromide, the target DNA can be indirectly detected by using an ethidium ion-selective electrode [103]. Despite the simplicity and versatility of the method, the sensitivity of the ethidium ion-selective electrode needs to be improved.

Peptide nucleic acid (PNA) is a potent DNA mimic having a polyamide backbone instead of the polyanionic phosphodiester backbone, which makes it electrically neutral and stable against nucleases and proteases. PNA has demonstrated remarkable hybridization properties towards the DNA counterpart by increasing thermal stability of the hybrids. Miyahara et al. reported a label-free potentiometric method for detecting DNA hybridization using PNA probes [104]. In this protocol, the hybridization at the solution/ electrode interface on the self-assembled monolayer-formed microelectrodes can lead to the change in the charge density, which is directly transformed into potentiometric signals. Moreover, the incorporation of PNA into ion channel-mimetic sensors can be useful for potentiometric DNA detection based on the target-
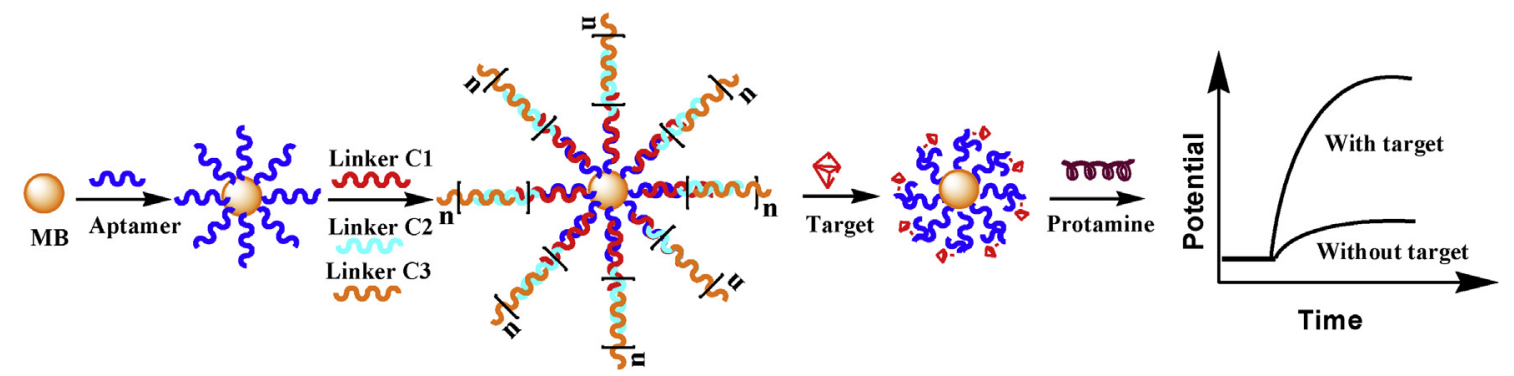

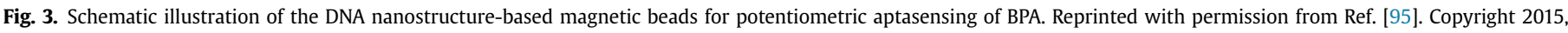
American Chemical Society. 
binding modulated flux of the marker ions (as shown in Fig. 5). In order to achieve stable responses with good analytical performance, the interface between electrode materials and a solution has to be designed correctly, depending on applications of the biosensors. For example, the graphene/electrolyte interfaces are not understood well as pointed out in the literature [105].

MicroRNAs (miRNA), as single-strand RNAs that conduct posttranscriptional gene regulation, are associated with a wide range of biological processes, such as cell proliferation, apoptosis and death. Therefore, simple analytical techniques to allow for an accurate, sensitive, selective, and cost effective miRNA analysis toward understanding the functions of miRNAs are highly required. The ongoing research of electrochemical miRNA sensing could play an important role in miRNA detection and quantification [106]. To date, few potentiometric detection methods are available for miRNA. In 2012, direct potentiometric detection of encapsulated miRNAs in exosomes was achieved using a microelectrode array after a reverse transcription polymerase chain reaction [107]. Integrated with a potentiometric chip, this technique may open a path to potentiometric diagnostics of miRNA in a noninvasive manner.

It should be noted that albeit substantial progress has been accomplished for potentiometric DNA/RNA sensing, the sensitivities of these above mentioned sensing protocols can be improved further by using various in vitro nucleic acid amplification techniques and more than one stage amplification protocols.

\subsection{Enzymes and proteins}

Enzymes are biological catalysts of great scientific and economic importance. Accordingly, many efforts have been made to develop simple, reliable, and cost-effective assays for the rapid detection of their catalytic activities. By selecting proper substrates, the enzyme activities can be determined by detecting ions generated by the enzymatic reactions using corresponding ISEs. Potentiometric assays for horseradish peroxidase [108], alkaline phosphate [109], butyrylcholinesterase [90], thrombin [110], and trypsin [111] are available. For example, Ding et al. reported a simple, general and label-free potentiometric method to measure nuclease activities in a homogeneous solution using a polycation-sensitive membrane electrode [112]. Measurements using protamine as an indicator were done with both the titration mode and direct detection mode.

Different potentiometric strategies have been explored for the detection of protein molecules. Some proteins have their own isoelectric points. The protein adsorption leads to the change of the concentration of the opposite charged ions, which can be detected using the ISEs [113]. However, a practical sensor should exhibit good sensitivity and selectivity, which could be realized by appropriate selection of the capture molecules. There are four different potentiometric sensing protocols for proteins based on bioreceptors (Fig. 6). Among various bioreceptors available, only a few have been applied for potentiometric detection of proteins (Fig. 6A). Metallothionein (MT), a metal-binding peptide was recombinantly (E. coli) synthesized as Zn7-MT complexes and used as receptor in a polysulfone matrix for potentiometric isoformselective detection of metallothionein. Its response mechanism could be close to that described for ion-exchange resin membranes, which depend on the interaction between the ionophore and the analyte [114].

The direct detection format based on the immunoreactioninduced electrical charge difference on the electrode surface has been recognized as a simple method (as shown in Fig. 6B). In recent years, many achievements have been made by nanotechnology. Ibupoto et al. introduced monoclonal antibody functionalized $\mathrm{ZnO}$ nanomaterials for direct potentiometric measurements of C-reactive protein, d-dimer and Notch 3 [115-117]. DNA or aptamer sequences have also been used as recognition elements for direct potentiometric detection of proteins. Goda et al. introduced dual aptamers onto a gold substrate to increase the affinity through multiple target binding. Taking thrombin as an example, a labelfree and reagent-less potentiometric biosensor was designed [118]. This methodology lies in the design of a biorecognition interface within an electrical double layer. Molecular imprinting allows creation of artificial receptors with antibody-like binding properties. In recent years, surface molecular imprinting with the imprinted sites close to the surface of molecular imprinted polymers is suitable for a template of bulky structure like protein. Protein-imprinted self-assembled monolayers with multiple binding sites can be used to design sensing elements for the direct potentiometric detection of cancer biomarkers and other proteins $[119,120]$. These methods are rather simple and do not require any labeling of probe.

As an alternative, the sensing mechanism based on a sandwich assay is the most frequently used [121-124] (as shown in Fig. 6C). Sandwich assays with enzyme tags or nanoparticle-based labels allow for signal generation and amplification through enzymatic reactions. Gyurcsányi et al. coupled paper-based assays with nanoparticle-based labels as signal transducers to develop a (a)

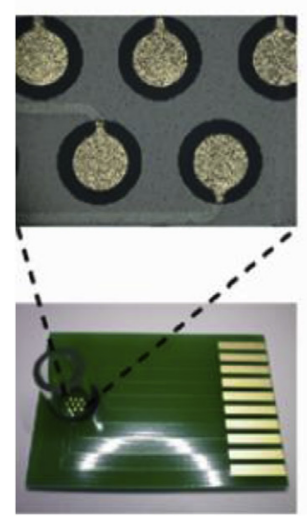

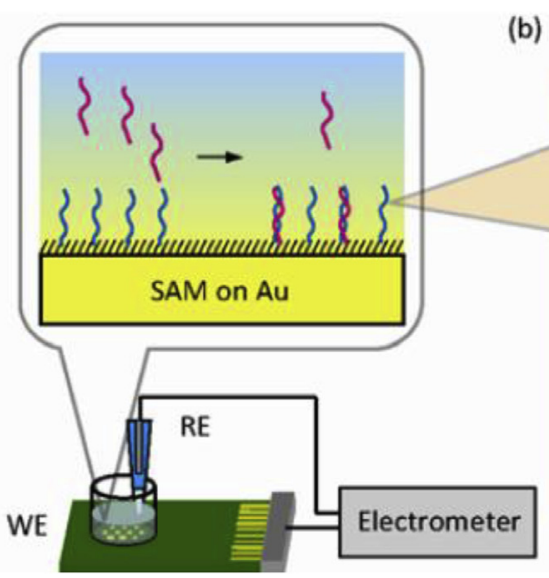

(b)

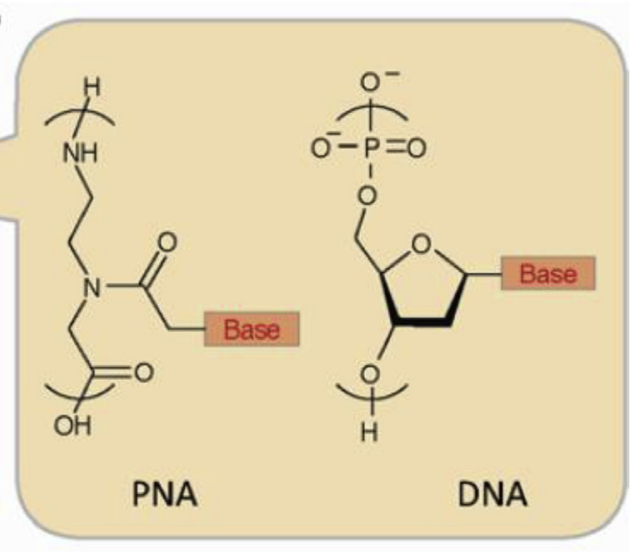

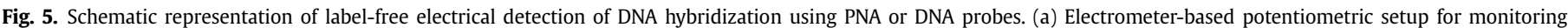

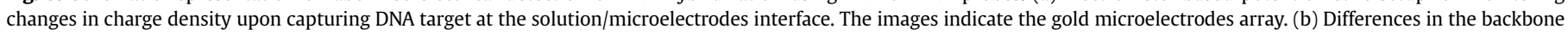
structure and electrostatic nature of PNA and DNA. Reprinted with permission from Ref. [104]. 
A
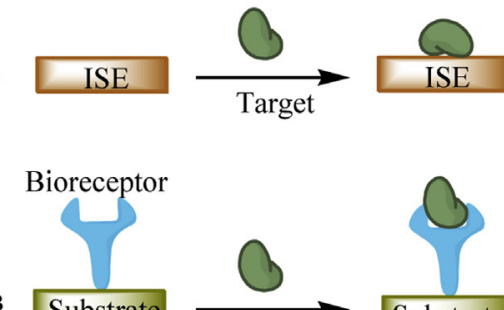

B

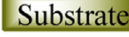

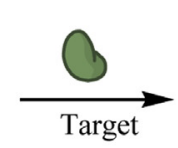

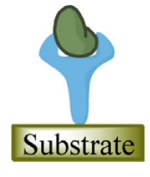

C

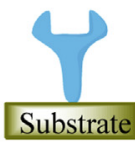

$\mathrm{D}$

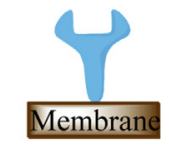

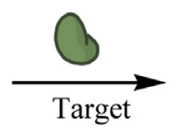
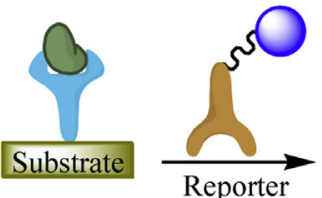

Substrate

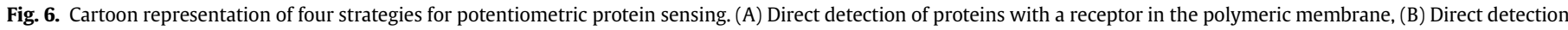
format based on the immunoreactions, (C) Sandwich assay format, and (D) Label-free detection format using indicator ions.

potentiometric sensing platform for proteins [125]. When combined with signal amplification strategies, the detection signal can be further enhanced.

Recently, ion-fluxes across polymeric membrane ISEs have been well understood and used as indicator ions for label-free potentiometric biosensing (as shown in Fig. 6D). Bakker et al. introduced a label-free potentiometric sensor principle for the detection of antibody-antigen and carbohydrate-concanavalin A interactions [126,127] (Fig. 7A). In this method, a quaternary ammonium ion is served as the marker ion to report the immunobinding event at the sensing surface. The target-binding can retard the marker ion, which results in its accumulation at the membrane surface and hence a potential response. The sensing principle is also validated for the determination of rhMBP [128]. Later, a novel potentiometric enzyme immunoassay based on pulsed galvanostatic controlled release of an enzyme substrate was also reported [109] (Fig. 7B). After the immunoreactions, the captured enzyme-labeled antibody catalyzes the hydrolysis of the substrate ions released at the samplemembrane interface. This sensing process can be potentiometrically determined by measuring the open circuit potential of the ISE. Recently, Liang et al. developed a label-free strategy for potentiometric sensing of bioanalytes making use of the flux of the indicator ion from the sample solution to the sensing membrane [129]. Heparin as a polyion was used as the indicator to induce large signals. The blocking effect induced by the recognition reaction between the mussel-inspired surface-imprinted polymer and trypsin was monitored by pulsed galvanostatic chronopotentiometry.

\subsection{Bacteria cells}

The detection and identification of pathogens in a rapid, reliable, specific and sensitive way is of great importance for food safety, clinical diagnosis and environmental surveillance. As a simplest, widespread, and field portable methodology, potentiometry based

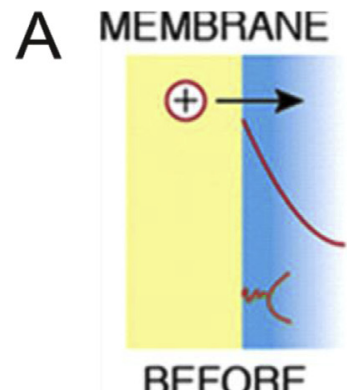

BEFORE
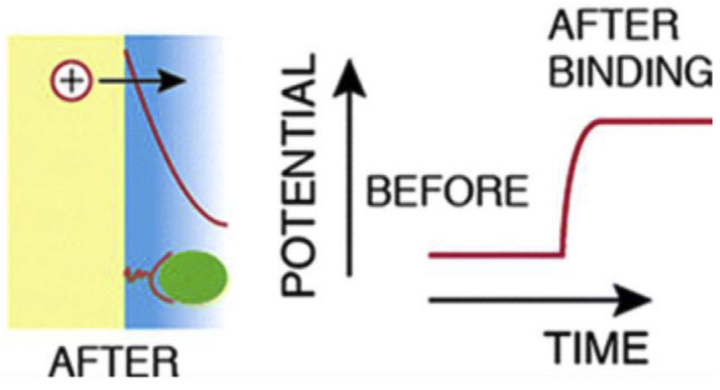
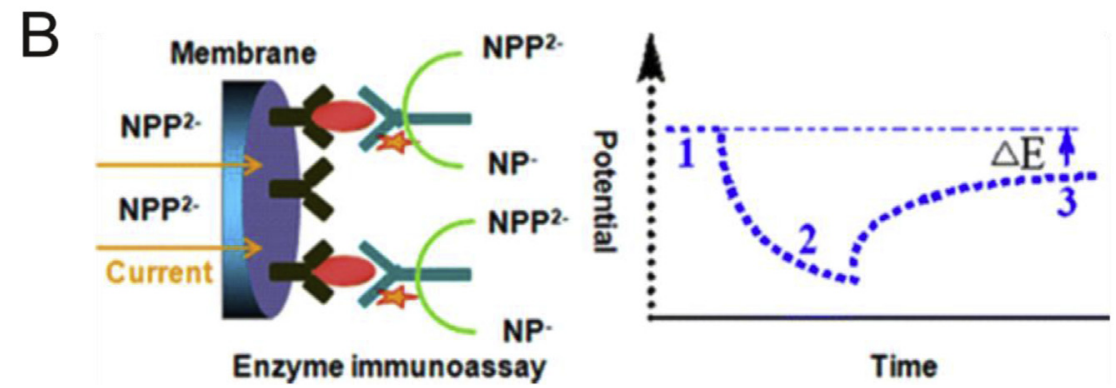

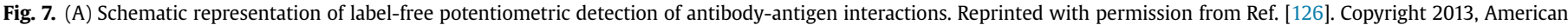

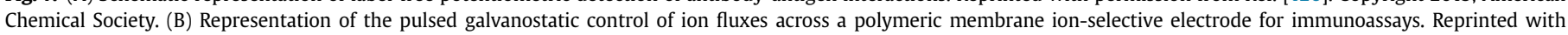
permission from Ref. [109]. Copyright 2013, American Chemical Society. 
on ISEs represent a promising tool for determination of bacteria by using bio-recognition elements including antibodies, aptamers, and antimicrobial peptides.

Owing to the generic and modular nature of the aptamer, versatile aptasensors have been designed to detect a wide range of bacteria species where specific binding aptamer can be selected [130]. Rius's group developed carbon nanotube based potentiometric aptasensors for which aptamer functionalized carbon nanotubes were used as probes to selectively and rapidly detect and identify a particular strain of bacteria cells. Carbon nanotubes were functionalized with aptamers either via non-covalent adsorption through $\pi-\pi$ stacking interactions or covalent binding between amine-modified aptamers and carboxylated carbon nanotubes $[131,132]$. In the presence of the target bacterial cells, the targetrecognition induced conformational changes in the linked aptamers can switch the surface charge on the SWCNT layer and the potential responses of the electrode. In a similar way, a graphenebased aptasensor, whose ultrasensitive performance outperforms the results obtained with carbon nanotubes as transduction layer, was proposed by the same group [133]. However, this technique typically requires aptamer labeling and immobilization. These processes not only involve extra time and cost but also affect the binding affinities between bacteria and aptamers. Qin's group developed a label-free potentiometric aptasensing strategy for rapid, sensitive and selective detection of bacteria [134]. An aptamer binds specifically to internalin $\mathrm{A}$, a surface protein present in Listeria monocytogenes cells, was selected as a model. The targetbinding induced conformational change of aptamer prevents the aptamer from electrostatically interacting with the protamine, which can be sensitively detected using a polycation-sensitive membrane electrode (as shown in Fig. 8A). Coupled to an online filtration system, the bioassay can be applied in coastal seawater sample [135]. Moreover, aptamer can be incorporated into DNAnanostructure modified magnetic beads for signal amplification [136]. This sensing protocol is readily adaptable to detect other bacteria by choosing the aptamers.

In contrast to antibodies and aptamers, peptides are intrinsically more stable in harsh environments. Qin and his coworkers designed a potentiometric sandwich assay for bacteria involving peptide pairs derived from an antimicrobial peptide ligand [137] (as shown in Fig. 8B). The magnetic beads-based sandwich assay could eliminate the background interferences from the complex matrixes for potentiometric measurements.

\subsection{Toxicities}

There is a strong need for the development of relatively rapid and low-cost bioassays for determination of toxicities in the environment and in industrial wastewaters. Various bioassays based on the change in the physiological response of a living organisms are available. Bacteria with enormous species diversity, rapid growth rates, low cost and easy maintenance have been used as test organisms for the assessment of water quality and pollution. Qin's group report on a flow biosensing mode for the detection of toxicity in water using the ammonia-oxidizing bacterium (AOB) Nitrosomonas europaea as a bioreceptor and a polymeric membrane ammonium-selective electrode as a detector [138]. The AOB cells were immobilized on polyether sulfone membranes packed upstream in a holder, which allowed the molecular recognition and transduction processes to be done individually. The inhibition effects of toxicants on the activity of $\mathrm{AOB}$ were evaluated by measuring the ammonium consumption rates with the ammonium-selective membrane electrode. A microbial biosensor with genetically engineered microorganisms can further improve the sensitivity and selectivity of the biosensor.

Many factors in a cell's environment have an impact on cellular metabolism. Given a sufficiently sensitive method for measuring mtatablic ions, it should be possible to detect or screen a wide variety of chemical and physical stimuli. For example, the alterations in intracellular ions during chemically induced apoptosis were investigated by using ion-selective microelectrode [139]. By integration of potentiometry with microscopic image [140], the proposed platform holds promise as a tool for minimally invasive dynamic analyses of single cells and toxins detection (as shown in Fig. 9).

\subsection{Other applications}

As a simple, rapid and effective sensing technology for ions, ISEs have been used as a promising tool for biological applications. As a
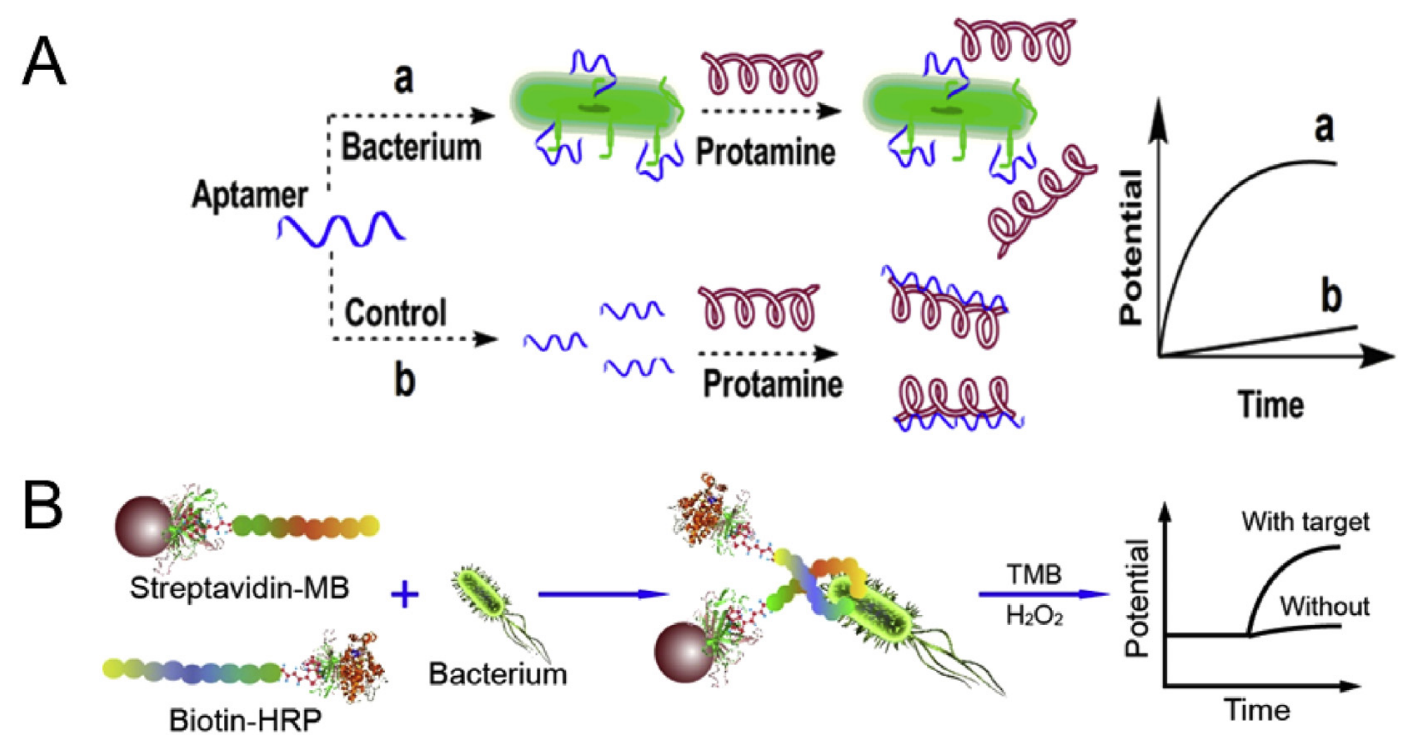

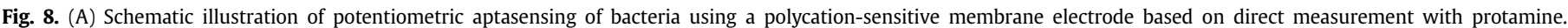

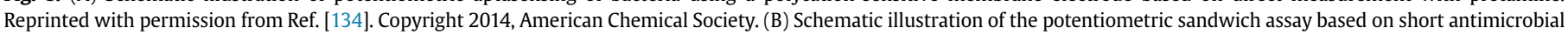
peptide pairs for detection of Listeria monocytogenes. Reprinted with permission from Ref. [137]. Copyright 2018, American Chemical Society. 


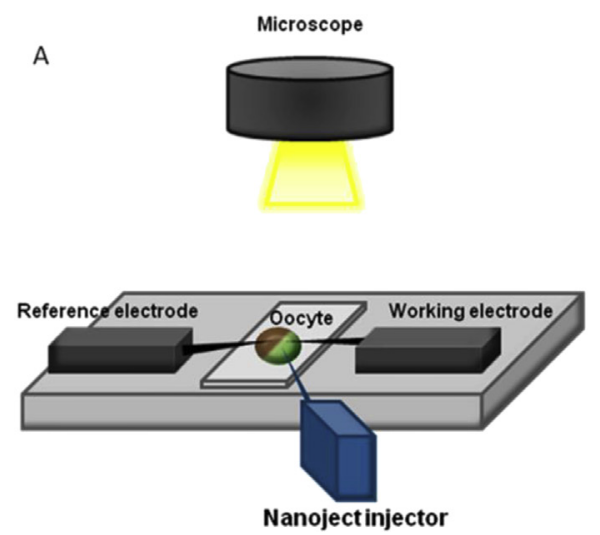


incorporation of various signal amplification strategies into the assay protocols can achieve high sensitivity.

Due to the development of solid contact ISEs and increasing availability of various nanomaterials, miniaturized ISEs or nanoscale potentiometry have gained increasing interest in the field of biological applications [148]. The use of new materials can improve the detection limit, biocompatibility, and sensor stability of ISEs. Bearing in mind trends in micro-fabrication and nanotechnology, miniaturized ISEs, especially solid-contact microelectrodes, have become a unique tool to investigate in life sciences and environmental monitoring. Also, microfluidic-based analytical devices ( $\mu$ PADs) have emerged as an attractive analytical and detection platform for the development of simple and cost-effective molecular diagnostic assays [90,149]. The integration of $\mu$ PADs with potentiometric ISEs enables the development of flexible, portable, and inexpensive biosensing devices. Moreover, the combination of ISEs with an inexpensive, mobile and handheld electrochemical device enables potentiometric sensing or biosensing in resourcelimited applications.

Biocompatibility is of great concern in applications of ISEs for potentiometric ion sensing and biosensing [150]. Biofouling can cause reduction of the sensitivity or even loss of the functionality of the ISEs. Biocompatibility of ISEs cannot only reduce the biofouling problems but also eliminate the toxic and inflammatory effect in the case of in vivo diagnosis. One of the key strategies to reduce the biofouling and improve the biocompatibility is to design the surface with chemical modification and antifouling coating [151-153]. The search for new materials with antifouling properties is not easy but of great promising [154].

In summary, with the introduction of new materials, versatility in sensor design, and the development of new sensing principles, polymeric membrane ISEs have been proved to be an excellent tool for potentiometric biosensing. Their applications in biosensing areas are promising and will be further explored.

\section{Acknowledgements}

This work was financially supported by the National Natural Science Foundation of China (41876108, 21575158 and 21677172), the funding from Laboratory for Marine Biology and Biotechnology, Pilot National Laboratory for Marine Science and Technology (Qingdao, OF2018NO01), the Instrument Developing Project of the Chinese Academy of Sciences (Y728021021), the National Key Research and Development Program of China (No. 2016YFC1400700), and the Taishan Scholar Program of Shandong Province (tspd20181215, tsqn201909163) and Key Research and Development Program of Yantai (2018ZHGY053).

\section{References}

[1] D.W. Kimmel, G. LeBlanc, M.E. Meschievitz, D.E. Cliffel, Electrochemical sensors and biosensors, Anal. Chem. 84 (2012) 685-707.

[2] A.P.F. Turner, Biosensors: sense and sensibility, Chem. Soc. Rev. 42 (2013) 3184-3196.

[3] E. Bakker, P. Bühlmann, E. Pretsch, Carrier-based ion-selective electrodes and bulk optodes. 1. General characteristics, Chem. Rev. 97 (1997) 3083-3132.

[4] P. Bühlmann, E. Pretsch, E. Bakker, Carrier-based ion-selective electrodes and bulk optodes. 2. Ionophores for potentiometric and optical sensors, Chem. Rev. 98 (1998) 1593-1687.

[5] E. Bakker, E. Pretsch, Modern potentiometry, Angew. Chem. Int. Ed. 46 (2007) 5660-5668.

[6] L.D. Chen, Philippe Bühlmann, Ion-selective electrodes with ionophoredoped sensing membranes, John Wiley \& Sons, 2012.

[7] T. Sokalski, A. Ceresa, T. Zwickl, E. Pretsch, Large improvement of the lower detection limit of ion-selective polymer membrane electrodes, J. Am. Chem. Soc. 119 (1997) 11347-11348.

[8] A. Malon, T. Vigassy, E. Bakker, E. Pretsch, Potentiometry at trace levels in confined samples: ion-selective electrodes with subfemtomole detection limits, J. Am. Chem. Soc. 128 (2006) 8154-8155.
[9] S.C. Ma, V.C. Yang, M.E. Meyerhoff, Heparin-responsive electrochemical sensor-A preliminary study, Anal. Chem. 64 (1992) 694-697.

[10] B. Fu, E. Bakker, J.H. Yun, V.C. Yang, M.E. Meyerhoff, Response mechanism of polymeric membrane-based potentiometric polyion sensors, Anal. Chem. 66 (1994) 2250-2259.

[11] M.E. Meyerhoff, B. Fu, E. Bakker, J.H. Yun, V.C. Yang, Polyion-sensitive membrane electrodes for biomedical analysis, Anal. Chem. 68 (1996) A168-A175.

[12] J. Bobacka, A. Ivaska, A. Lewenstam, Potentiometric ion sensors, Chem. Rev. 108 (2008) 329-351.

[13] E. Lindner, R.E. Gyurcsányi, Quality control criteria for solid-contact, solvent polymeric membrane ion-selective electrodes, J. Solid State Electrochem. 13 (2009) 51-68.

[14] A. Duzgun, G.A. Zelada-Guillen, G.A. Crespo, S. Macho, J. Riu, F.X. Rius, Nanostructured materials in potentiometry, Anal. Bioanal. Chem. 399 (2011) $171-181$.

[15] T.J. Yin, W. Qin, Applications of nanomaterials in potentiometric sensors, TrAC, Trends Anal. Chem. 51 (2013) 79-86.

[16] U. Vanamo, J. Bobacka, Instrument-free control of the standard potential of potentiometric solid-contact ion-selective electrodes by short-circuiting with a conventional reference electrode, Anal. Chem. 86 (2014) $10540-10545$.

[17] X.U. Zou, X.V. Zhen, J.H. Cheong, P. Bühlmann, Calibration-free ionophorebased ion-selective electrodes with a $\mathrm{Co}(\mathrm{II}) / \mathrm{Co}$ (III) redox couple-based solid contact, Anal. Chem. 86 (2014) 8687-8692.

[18] J.B. Hu, A. Stein, P. Bühlmann, Rational design of all-solid-state ion-selective electrodes and reference electrodes, TrAC, Trends Anal. Chem. 76 (2016) $102-114$

[19] U. Guth, F. Gerlach, M. Decker, W. Oelssner, W. Vonau, Solid-state reference electrodes for potentiometric sensors, J. Solid State Electrochem. 13 (2009) 27-39.

[20] K. Granholm, Z. Mousavi, T. Sokalski, A. Lewenstam, Analytical quality solidstate composite reference electrode manufactured by injection moulding, J. Solid State Electrochem. 18 (2014) 607-612.

[21] Z. Mousavi, K. Granholm, T. Sokalski, A. Lewenstam, All-solid-state electrochemical platform for potentiometric measurements, Sens. Actuators, B 207 (2015) 895-899.

[22] J.B. Hu, K.T. Ho, X.U. Zou, W.H. Smyrl, A. Stein, P. Bühlmann, All-solid-state reference electrodes based on colloid-imprinted mesoporous carbon and their application in disposable paper-based potentiometric sensing devices, Anal. Chem. 87 (2015) 2981-2987.

[23] E. Lindner, M. Guzinski, T.A. Khan, B.D. Pendley, Reference electrodes with ionic liquid salt bridge: when will these innovative novel reference electrodes gain broad acceptance? ACS Sens. 4 (2019) 549-561.

[24] X.V. Zhen, C.R. Rousseau, P. Bühlmann, Redox buffer capacity of ion-selective electrode solid contacts doped with organometallic complexes, Anal. Chem. 90 (2018) 11000-11007.

[25] T.T. Han, U. Mattinen, J. Bobacka, Improving the sensitivity of solid-Contact ion-selective electrodes by using coulometric signal transduction, ACS Sens. 4 (2019) 900-906.

[26] E. Zdrachek, E. Bakker, Electrochemically switchable polymeric membrane ion-selective electrodes, Anal. Chem. 90 (2018) 7591-7599.

[27] M. Guzinski, J.M. Jarvis, P. D'Orazio, A. Izadyar, B.D. Pendley, E. Lindner, Solidcontact $\mathrm{pH}$ sensor without $\mathrm{CO}_{2}$ interference with a superhydrophobic PEDOT-C14 as solid contact: the ultimate "water layer" test, Anal. Chem. 89 (2017) 8468-8475.

[28] N. He, S. Papp, T. Lindfors, L. Höfler, R.M. Latonen, R.E. Gyurcsányi, Prepolarized hydrophobic conducting polymer solid-contact ion-selective electrodes with improved potential reproducibility, Anal. Chem. 89 (2017) 2598-2605

[29] G.T. Zhao, R.N. Liang, F.F. Wang, J.W. Ding, W. Qin, An all-solid-state potentiometric microelectrode for detection of copper in coastal sediment porewater, Sens. Actuators, B 279 (2019) 369-373.

[30] S. Papp, M. Bojtár, R.E. Gyurcsányi, T. Lindfors, Potential reproducibility of potassium-selective electrodes having perfluorinated alkanoate side chain functionalized poly(3,4-ethylenedioxytiophene) as a hydrophobic solid contact, Anal. Chem. 91 (2019) 9111-9118.

[31] M. Parrilla, M. Cuartero, S. Padrell Sánchez, M. Rajabi, N. Roxhed, F. Niklaus, G.A. Crespo, Wearable all-solid-state potentiometric microneedle patch for intradermal potassium detection, Anal. Chem. 91 (2019) 1578-1586.

[32] D. Kałuża, E. Jaworska, M. Mazur, K. Maksymiuk, A. Michalska, Multiwalled carbon nanotubes-poly(3-octylthiophene-2,5-diyl) nanocomposite transducer for ion-selective electrodes: Raman spectroscopy insight into the transducer/membrane interface, Anal. Chem. 91 (2019) 9010-9017.

[33] J.H. Shim, J. Kim, G.S. Cha, H. Nam, R.J. White, H.S. White, R.B. Brown, Glass nanopore-based ion-selective electrodes, Anal. Chem. 79 (2007) $3568-3574$.

[34] Y.D. Xu, E. Bakker, Ion channel mimetic chronopotentiometric polymeric membrane ion sensor for surface-confined protein detection, Langmuir 25 (2009) 568-573.

[35] G. Jagerszki, A. Takacs, I. Bitter, R.E. Gyurcsányi, Solid-state ion channels for potentiometric sensing, Angew. Chem. Int. Ed. 50 (2011) 1656-1659.

[36] E. Pergel, R.E. Gyurcsányi, K. Toth, E. Lindner, Picomolar detection limits with current-polarized $\mathrm{Pb}^{2+}$ ion-selective membranes, Anal. Chem. 73 (2001) 4249-4253. 
[37] A. Shvarev, E. Bakker, Reversible electrochemical detection of nonelectroactive polyions, J. Am. Chem. Soc. 125 (2003) 11192-11193.

[38] V. Bhakthavatsalam, A. Shvarev, E. Bakker, Selective coulometric release of ions from ion selective polymeric membranes for calibration-free titrations, Analyst 131 (2006) 895-900.

[39] J.W. Ding, W. Qin, Current-driven ion fluxes of polymeric membrane ionselective electrode for potentiometric biosensing, J. Am. Chem. Soc. 131 (2009) 14640-14641.

[40] E. Grygolowicz-Pawlak, E. Bakker, Thin layer coulometry with ionophore based ion-selective membranes, Anal. Chem. 82 (2010) 4537-4542.

[41] E. Bakker, Membrane response model for ion-selective electrodes operated by controlled-potential thin-layer coulometry, Anal. Chem. 83 (2011) 486-493.

[42] M.G. Afshar, G.A. Crespo, D. Dorokhin, B. Neel, E. Bakker, Thin layer coulometry of nitrite with ion-selective membranes, Electroanalysis 27 (2015) 609-615.

[43] E. Bakker, Enhancing ion-selective polymeric membrane electrodes by instrumental control, TrAC, Trends Anal. Chem. 53 (2014) 98-105.

[44] E. Bakker, Electroanalysis with membrane electrodes and liquid-liquid interfaces, Anal. Chem. 88 (2016) 395-413.

[45] M.G. Afshar, G.A. Crespo, E. Bakker, Direct ion speciation analysis with ionselective membranes operated in a sequential potentiometric/time resolved chronopotentiometric sensing mode, Anal. Chem. 84 (2012) 8813-8821.

[46] G.A. Crespo, M.G. Afshar, E. Bakker, Reversible sensing of the anticoagulant heparin with protamine permselective membranes, Angew. Chem. Int. Ed. 51 (2012) 12575-12578.

[47] E. Hupa, U. Vanamo, J. Bobacka, Novel ion-to-electron transduction principle for solid-contact ISEs, Electroanalysis 27 (2015) 591-594.

[48] U. Vanamo, E. Hupa, V. Yrjana, J. Bobacka, New signal readout principle for solid-contact ion-selective electrodes, Anal. Chem. 88 (2016) 4369-4374.

[49] M. Cuartero, G.A. Crespo, E. Bakker, Polyurethane ionophore-based thin layer membranes for voltammetric ion activity sensing, Anal. Chem. 88 (2016) 5649-5654.

[50] X. Nagy, L. Höfler, Lowering detection limits toward target ions using quasisymmetric polymeric ion-selective membranes combined with amperometric measurements, Anal. Chem. 88 (2016) 9850-9855.

[51] G.A. Crespo, G. Mistlber, E. Bakker, Electrogenerated chemiluminescence for potentiometric sensors, J. Am. Chem. Soc. 134 (2012) 205-207.

[52] J.W. Ding, E.G. Lv, L.Y. Zhu, W. Qin, Optical ion sensing platform based on potential-modulated release of enzyme, Anal. Chem. 89 (2017) 3235-3239.

[53] W.Y. Gao, S. Jeanneret, D.J. Yuan, T. Cherubin, L. Wang, X.J. Xie, E. Bakker, Electrogenerated chemiluminescence for chronopotentiometric sensors, Anal. Chem. 91 (2019) 4889-4895.

[54] E. Bakker, Can calibration-free sensors be realized? ACS Sens. 1 (2016) $838-841$.

[55] W.J. Lan, X.U. Zou, M.M. Hamedi, J.B. Hu, C. Parolo, E. Jane Maxwell, P. Bühlmann, G.M. Whitesides, Paper-based potentiometric ion sensing, Anal. Chem. 86 (2014) 9548-9553.

[56] N. Pankratova, G.A. Crespo, M.G. Afshar, M.C. Crespi, S. Jeanneret, T. Cherubini, M.L. Tercier-Waeber, F. Pomati, E. Bakker, Potentiometric sensing array for monitoring aquatic systems, Environ. Sci. Proc. Impacts 17 (2015) 906-914.

[57] M. Parrilla, M. Cuartero, G.A. Crespo, Wearable potentiometric ion sensors, TrAC, Trends Anal. Chem. 110 (2019) 303-320.

[58] M. Parrilla, R. Canovas, I. Jeerapan, F.J. Andrade, J. Wang, A textile-based stretchable multi-ion potentiometric sensor, Adv. Healthc. Mater. 5 (2016) 996-1001.

[59] W. Gao, S. Emaminejad, H.Y.Y. Nyein, S. Challa, K. Chen, A. Peck, H.M. Fahad, H. Ota, H. Shiraki, D. Kiriya, D.H. Lien, G.A. Brooks, R.W. Davis, A. Javey, Fully integrated wearable sensor arrays for multiplexed in situ perspiration analysis, Nature 529 (2016) 509-514.

[60] A. Nemiroski, D.C. Christodouleas, J.W. Hennek, A.A. Kumar, E.J. Maxwell, M. Teresa Fernandez-Abedul, G.M. Whitesides, Universal mobile electrochemical detector designed for use in resource-limited applications, Proc. Natl. Acad. Sci. 111 (2014) 11984-11989.

[61] E. Zdrachek, E. Bakker, Potentiometric sensing, Anal. Chem. 91 (2019) 2-26.

[62] E. Zdrachek, E. Bakker, From molecular and emulsified ion sensors to membrane electrodes: molecular and mechanistic sensor design, Acc. Chem. Res. 52 (2019) 1400-1408.

[63] T. Sakata, Biologically coupled date field-effect transistors meet in vitro diagnostics, ACS Omega 4 (2019) 11852-11862.

[64] J.M. Rothberg, W. Hinz, T.M. Rearick, J. Schultz, W. Mileski, M. Davey, J.H. Leamon, K. Johnson, M.J. Milgrew, M. Edwards, J. Hoon, J.F. Simons, D. Marran, J.W. Myers, J.F. Davidson, A. Branting, J.R. Nobile, B.P. Puc, D. Light, T.A. Clark, M. Huber, J.T. Branciforte, I.B. Stoner, S.E. Cawley, M. Lyons, YT. Fu, N. Homer, M. Sedova, X. Miao, B. Reed, J. Sabina, E. Feierstein, M. Schorn, M. Alanjary, E. Dimalanta, D. Dressman, R. Kasinskas, T. Sokolsky, J.A. Fidanza, E. Namsaraev, K.J. McKernan, A. Williams, G. Thomas Roth, J. Bustillo, An integrated semiconductor device enabling non-optical genome sequencing, Nature 475 (2011) 348-352.

[65] C. Toumazou, L.M. Shepherd, S.C. Reed, G.I. Chen, A. Patel, D.M. Garner, C.A. Wang, C.P. Ou, K. Amin-Desai, P. Athanasiou, H. Bai, I.M.Q. Brizido, B. Caldwell, D. Coomber-Alford, P. Georgiou, K.S. Jordan, J.C. Joyce, M.L. Mura, D. Morley, S. Sathyavruthan, S. Temelso, R.E. Thomas, L.L. Zhang,
Simultaneous DNA amplification and detection using a pH-sensing semiconductor system, Nat. Methods 10 (2013) 641-648.

[66] D.S. Juang, C.H. Lin, Y.R. Huo, C.Y. Tang, C.R. Cheng, H.S. Wu, S.F. Huang A. Kalnitsky, C.C. Lin, Proton-ELISA: electrochemical immunoassay on a dualgated ISFET array, Biosens. Bioelectron. 117 (2018) 175-182.

[67] E. Lindner, B.D. Pendley, A tutorial on the application of ion-selective electrode potentiometry: an analytical method with unique qualities, unexplored opportunities and potential pitfall, Anal. Chim. Acta 762 (2013) 1-13.

[68] A.J. Bandodkar, D. Molinnus, O. Mirza, T. Guinovart, J.R. Windmiller G. Valdes-Ramirez, F.J. Andrade, M.J. Schoening, J. Wang, Epidermal tattoo potentiometric sodium sensors with wireless signal transduction for continuous non-invasive sweat monitoring, Biosens. Bioelectron. 54 (2014) 603-609.

[69] A. Gonzalez-Bellavista, S. Atrian, M. Munoz, M. Capdevila, E. Fabregas, Novel potentiometric sensors based on polysulfone immobilized metallothioneins as metal-ionophores, Talanta 77 (2009) 1528-1533.

[70] B. Viguier, K. Zor, E. Kasotakis, A. Mitraki, C.H. Clausen, W.E. Svendsen, J. Castillo-Leon, Development of an electrochemical meta-ion biosensor using self-assembled peptide nanofibrils, ACS Appl. Mater. Interfaces 3 (2011) 1594-1600.

[71] S. Papp, G. Jágerszki, R.E. Gyurcsányi, Ion-selective electrodes based on hydrophilic ionophore-modified nanopores, Angew. Chem. Int. Ed. 57 (2018) $4752-4755$.

[72] J.W. Ding, W. Qin, Y. Zhang, X.W. Wang, Potentiometric aptasensing based on target-induced conformational switch of a DNA probe using a polymeric membrane silver ion-selective electrode, Biosens. Bioelectron. 45 (2013) $148-151$.

[73] J. Liu, Z. Cao, Y. Lu, Functional nucleic acid sensors, Chem. Rev. 109 (2009) $1948-1998$.

[74] C.O. Chey, Z.H. Ibupoto, K. Khun, O. Nur, M. Willander, Indirect determination of mercury ion by inhibition of a glucose biosensor based on $\mathrm{ZnO}$ nanorods, Sensors 12 (2012) 15063-15077.

[75] G.l.M. Lara Tess Bereza-Malcolm, Ashley Edwin Franks, Environmenta sensing of heavy metals through whole cell microbial biosensors: a synthetic biology approach, ACS Synth. Biol. 4 (2014) 535-546.

[76] S.K. Arya, S. Saha, J.E. Ramirez-Vick, V. Gupta, S. Bhansali, S.P. Singh, Recent advances in $\mathrm{ZnO}$ nanostructures and thin films for biosensor applications: review, Anal. Chim. Acta 737 (2012) 1-21.

[77] M.Q. Israr, J.R. Sadaf, O. Nur, M. Willander, S. Salman, B. Danielsson, Chemically fashioned $\mathrm{ZnO}$ nanowalls and their potential application for potentiometric cholesterol biosensor, Appl. Phys. Lett. 98 (2011)

[78] V.N. Psychoyios, G.P. Nikoleli, N. Tzamtzis, D.P. Nikolelis, N. Psaroudakis B. Danielsson, M.Q. Israr, M. Willander, Potentiometric cholesterol biosensor based on ZnO nanowalls and stabilized polymerized lipid film, Electroanalysis 25 (2013) 367-372.

[79] K. Khun, Z.H. Ibupoto, O. Nur, M. Willander, Development of galactose biosensor based on functionalized $\mathrm{ZnO}$ nanorods with galactose oxidase, J. Sens. (2012). https://doi.org/10.1155/2012/696247.

[80] Z.H. Ibupoto, S.M.U.A. Shah, K. Khun, M. Willander, Electrochemical L-lactic acid sensor based on immobilized $\mathrm{ZnO}$ nanorods with lactate oxidase, Sensors 12 (2012) 2456-2466.

[81] S.M.U. Ali, Z.H. Ibupoto, M. Kashif, U. Hashim, M. Willander, A potentiometric indirect uric acid sensor based on $\mathrm{ZnO}$ nanoflakes and immobilized uricase, Sensors 12 (2012) 2787-2797.

[82] C.S. Pundir, S. Yadav, A. Kumar, Creatinine sensors, TrAC, Trends Anal. Chem 50 (2013) 42-52.

[83] K. Saeedfar, L.Y. Heng, T.L. Ling, M. Rezayi, Potentiometric urea biosensor based on an immobilised fullerene-urease bioconjugate, Sensors 13 (2013) $16851-16866$

[84] P. Kang, X. Ma, M. Lin, X. Liu, J. Wang, Development of a potentiometric glucose biosensor based on a PVC membrane electrode, Acta Chim. Sinica 69 (2011) 3002-3006.

[85] E. Karakus, S. Pekyardimci, E. Kilic, Potentiometric glucose determination in human serum samples with glucose oxidase biosensor based on iodide electrode, Appl. Biochem. Microbiol. 49 (2013) 194-198.

[86] D. Yilmaz, E. Karakus, Construction of a potentiometric glutamate biosensor for determination of glutamate in some real samples, Artifi. Cell. Blood Sub 39 (2011) 385-391.

[87] M.N.M. Arip, L.Y. Heng, M. Ahmad, S. Ujang, A cell-based potentiometric biosensor using the fungus Lentinus sajor-caju for permethrin determination in treated wood, Talanta 116 (2013) 776-781.

[88] F.F. Geng, J.W. Ding, C.Y. Jia, B.J. Ding, W. Qin, A potentiometric biosensing system based on an isolated degrading bacterium Klebsiella sp MP-6 for the determination of methyl parathion, RSC Adv. 5 (2015) 34475-34480.

[89] N.N. Yu, J.W. Ding, W.W. Wang, X.D. Wang, W. Oin, Pulsed galvanostatic control of a solid-contact ion-selective electrode for potentiometric biosensing of microcystin-LR, Sens. Actuators, B 230 (2016) 785-790.

[90] J.W. Ding, B.W. Li, L.X. Chen, W. Qin, A three-dimensional origami paperbased device for potentiometric biosensing, Angew. Chem. Int. Ed. 55 (2016) 13033-13037.

[91] A.B. Iliuk, L. Hu, W.A. Tao, Aptamer in bioanalytical applications, Anal. Chem. 83 (2011) 4440-4452.

[92] D. Daems, K. De Wael, K. Vissenberg, G. Van Camp, L. Nagels, Potentiometric sensors doped with biomolecules as a new approach to small molecule 
biomolecule binding kinetics analysis, Biosens. Bioelectron. 54 (2014) 515-520.

[93] E.G. Lv, J.W. Ding, W. Qin, Potentiometric aptasensing of small molecules based on surface charge change, Sens. Actuators, B 259 (2018) 463-466.

[94] J.W. Ding, Y. Chen, X.W. Wang, W. Qin, Label-free and substrate-free potentiometric aptasensing using polycation-sensitive membrane electrodes, Anal. Chem. 84 (2012) 2055-2061.

[95] J.W. Ding, Y. G, F. li, H.X. Zhang, W. Qin, DNA nanostructure-based magnetic beads for potentiometric aptasensing, Anal. Chem. 87 (2015) 6465-6469.

[96] A. Numnuam, K.Y. Chumbimuni-Torres, Y. Xiang, R. Bash, P. Thavarungkul, P. Kanatharana, E. Pretsch, J. Wang, E. Bakker, Potentiometric detection of DNA hybridization, J. Am. Chem. Soc. 130 (2008) 410-411.

[97] K.Y. Chumbimuni-Torres, J. Wu, C. Clawson, M. Galik, A. Walter, G.U. Flechsig, E. Bakker, L. Zhang, J. Wang, Amplified potentiometric transduction of DNA hybridization using ion-loaded liposomes, Analyst 135 (2010) 1618-1623.

[98] R.M. Kakhki, Application of nanoparticles in the potentiometric ion selective electrodes, Russ. J. Electrochem. 49 (2013) 458-465.

[99] J. Wu, K.Y. Chumbimuni-Torres, M. Galik, C. Thammakhet, D.A. Haake, J. Wang, Potentiometric detection of DNA hybridization using enzymeinduced metallization and a silver ion selective electrode, Anal. Chem. 81 (2009) 10007-10012.

[100] J.W. Ding, N.N. Yu, X.W. Wang, W. Qin, Sequential and selective detection of two molecules with a single solid-contact chronopotentiometric ionselective electrode, Anal. Chem. 90 (2018) 1734-1739.

[101] X.W. Wang, Z.F. Ding, Q.W. Ren, W. Qin, Polymeric membrane neutral phenol-sensitive electrodes for potentiometric G-Quadruplex/Hemin DNAzyme-based biosensing, Anal. Chem. 85 (2013) 1945-1950.

[102] X.W. Wang, Y.G. Yang, L. Li, M.S. Sun, H.G. Yin, W. Qin, A polymeric liquid membrane electrode responsive to 3,3',5,5'-tetramethylbenzidine oxidation for sensitive peroxidase/peroxidase mimetic-based potentiometric biosensing, Anal. Chem. 86 (2014) 4416-4422.

[103] A. Seichi, N. Kozuka, Y. Kashima, M. Tabata, T. Goda, A. Matsumoto, N. Iwasawa, D. Citterio, Y. Miyahara, K. Suzuki, Real-time monitoring and detection of primer generation-rolling circle amplification of DNA using an ethidium ion-selective electrode, Anal. Sci. 32 (2016) 505-510.

[104] T. Goda, A.B. Singi, Y. Maeda, A. Matsumoto, M. Torimura, H. Aoki, Y. Miyahara, Label-free potentiometry for detecting DNA hybridization using peptide nucleic acid and DNA probes, Sensors 13 (2013) 2267-2278.

[105] J. Janata, Graphene bio-field-effect transistor myth, ECS Solid State Lett. 1 (2012) M29-M31.

[106] M. Labib, M.V. Berezovski, Electrochemical sensing of microRNAs: avenues and paradigms, Biosens. Bioelectron. 68 (2015) 83-94.

[107] T. Goda, K. Masuno, J. Nishida, N. Kosaka, T. Ochiya, A. Matsumoto, Y. Miyahara, A label-free electrical detection of exosomal microRNAs using microelectrode array, Chem. Commun. 48 (2012) 11942-11944.

[108] X.W. Wang, W. Qin, Reactive intermediates-induced potential responses of a polymeric membrane electrode for ultrasensitive potentiometric biosensing, Chem. Commun. 48 (2012) 4073-4075.

[109] J.W. Ding, X.W. Wang, W. Qin, Pulsed galvanostatic control of a polymeric membrane ion-selective electrode for potentiometric immunoassays, ACS Appl. Mater. Interfaces 5 (2013) 9488-9493.

[110] X.W. Wang, W. Qin, Tetra(p-tolyl)borate-functionalized solvent polymeric membrane: a facile and sensitive sensing platform for peroxidase and peroxidase mimetics, Chem. Eur J. 19 (2013) 9979-9986.

[111] Y. Chen, J.W. Ding, W. Qin, Potentiometric determination of trypsin using a polymeric membrane polycation-sensitive electrode based on currentcontrolled reagent delivery, Bioelectrochemistry 88 (2012) 144-147.

[112] J.W. Ding, W. Qin, Potentiometric sensing of nuclease activities and oxidative damage of single-stranded DNA using a polycation-sensitive membrane electrode, Biosens. Bioelectron. 47 (2013) 559-565.

[113] A. Prabhu, J. Bobacka, A. Ivaska, K. Levon, Investigation of protein binding with all solid-state ion-selective electrodes, Electroanalysis 25 (2013) 1887-1894

[114] M. Capdevila, A. Gonzalez-Bellavista, M. Munoz, S. Atrian, E. Fabregas, The first isoform-selective protein biosensor: a metallothionein potentiometric electrode, Chem. Commun. 46 (2010) 2040-2042.

[115] Z.H. Ibupoto, N. Jamal, K. Khun, X. Liu, M. Willander, A potentiometric immunosensor based on silver nanoparticles decorated $\mathrm{ZnO}$ nanotubes, for the selective detection of d-dimer, Sens. Actuators, B 182 (2013) $104-111$

[116] Z.H. Ibupoto, N. Jamal, K. Khun, M. Willander, Development of a disposable potentiometric antibody immobilized $\mathrm{ZnO}$ nanotubes based sensor for the detection of C-reactive protein, Sens. Actuators, B 166 (2012) 809-814.

[117] Z.H. Ibupoto, K. Khun, X. Liu, M. Willander, A potentiometric biosensor for the detection of Notch 3 using functionalized $\mathrm{ZnO}$ nanorods, J. Nanosci. Nanotechnol. 14 (2014) 6704-6710.

[118] T. Goda, D. Higashi, A. Matsumoto, T. Hoshi, T. Sawaguchi, Y. Miyahara, Dual aptamer-immobilized surfaces for improved affinity through multiple target binding in potentiometric thrombin biosensing, Biosens. Bioelectron. 73 (2015) 174-180.

[119] M. Rebelo, C. Santos, J. Costa-Rodrigues, M.H. Fernandes, J.P. Noronha, M.G.F. Sales, Novel prostate specific antigen plastic antibody designed with charged binding sites for an improved protein binding and its application in a biosensor of potentiometric transduction, Electrochim. Acta 132 (2014) $142-150$.
[120] A.P.M. Tavares, F.T.C. Moreira, M.G.F. Sales, Haemoglobin smart plastic antibody material tailored with charged binding sites on silica nanoparticles: its application as an ionophore in potentiometric transduction, RSC Adv. 3 (2013) 26210-26219.

[121] K.Y. Chumbimuni-Torres, Z. Dai, N. Rubinova, Y. Xiang, E. Pretsch, J. Wang, E. Bakker, Potentiometric biosensing of proteins with ultrasensitive ionselective microelectrodes and nanoparticle labels, J. Am. Chem. Soc. 128 (2006) 13676-13677.

[122] A. Numnuam, K.Y. Chumbimuni-Torres, Y. Xiang, R. Bash, P. Thavarungkul, P. Kanatharana, E. Pretsch, J. Wang, E. Bakker, Aptamer-based potentiometric measurements of proteins using ion-selective microelectrodes, Anal. Chem. 80 (2008) 707-712.

[123] R. Thuerer, T. Vigassy, M. Hirayama, J. Wang, E. Bakker, E. Pretsch, Potentiometric immunoassay with quantum dot labels, Anal. Chem. 79 (2007) 5107-5110.

[124] J. Szucs, E. Pretsch, R.E. Gyurcsányi, Potentiometric enzyme immunoassay using miniaturized anion-selective electrodes for detection, Analyst 134 (2009) 1601-1607.

[125] J. Szucs, R.E. Gyurcsányi, Towards protein assays on paper platforms with potentiometric detection, Electroanalysis 24 (2012) 146-152.

[126] M.S. Ozdemir, M. Marczak, H. Bohets, K. Bonroy, D. Roymans, L. Stuyver, K. Vanhoutte, M. Pawlak, E. Bakker, A label-free potentiometric sensor principle for the detection of antibody-antigen interactions, Anal. Chem. 85 (2013) 4770-4776.

[127] M. Pawlak, G. Mistlberger, E. Bakker, Concanavalin A electrochemical sensor based on the surface blocking principle at an ion-selective polymeric membrane, Microchim. Acta 182 (2015) 129-137.

[128] M.A. Al-Ghobashy, A.H. Nadim, G.M. El-Sayed, M. Nebsen, Label-free potentiometric ion flux immunosensor for determination of recombinant human myelin basic protein: application to downstream purification from transgenic milk, ACS Sens. 4 (2019) 413-420.

[129] R.N. Liang, J.W. Ding, S.S. Gao, W. Qin, Mussel-inspired surface imprinted sensors for potentiometric label-free biological species, Angew. Chem. Int. Ed. 56 (2016) 6833-6837.

[130] C.L.A. Hamula, H. Zhang, F. Li, Z. Wang, X.C. Le, X.-F. Li, Selection and analytical applications of aptamers binding microbial pathogens, TrAC, Trends Anal. Chem. 30 (2011) 1587-1597.

[131] G.A. Zelada-Guillen, P. Blondeau, F. Xavier Rius, J. Riu, Carbon nanotubebased aptasensors for the rapid and ultrasensitive detection of bacteria, Methods 63 (2013) 233-238.

[132] G.A. Zelada-Guillen, J. Luis Sebastian-Avila, P. Blondeau, J. Riu, F. Xavier Rius, Label-free detection of Staphylococcus aureus in skin using real-time potentiometric biosensors based on carbon nanotubes and aptamers, Biosens. Bioelectron. 31 (2012) 226-232.

[133] R. Hernandez, C. Valles, A.M. Benito, W.K. Maser, F. Xavier Rius, J. Riu, Graphene-based potentiometric biosensor for the immediate detection of living bacteria, Biosens. Bioelectron. 54 (2014) 553-557.

[134] J.W. Ding, J.H. Lei, X. Ma, J. Gong, W. Qin, Potentiometric aptasensing of Listeria monocytogenes using protamine as an indicator, Anal. Chem. 86 (2014) 9412-9416.

[135] J.H. Lei, J.W. Ding, W. Qin, A chronopotentiometric flow injection system for aptasensing of E. coli 0157, Anal. Methods 7 (2015) 825-829.

[136] G.T. Zhao, J.W. Ding, H. Yu, T.J. Yin, W. Qin, Potentiometric aptasensing of Vibrio alginolyticus based on DNA-nanostructure-modified magnetic beads, Sensors (2016) 2052.

[137] E.G. Lv, J.W. Ding, W. Qin, Potentiometric detection of Listeria monocytogenes via a short antimicrobial peptide pair-based sandwich assay, Anal. Chem. 90 (2018) 13600-13606.

[138] Q. Zhang, J. Ding, L. Kou, W. Qin, A potentiometric flow biosensor based on ammonia-oxidizing bacteria for the detection of toxicity in water, Sensors 13 (2013) 6936-6945.

[139] S.I. Borjesson, U.H. Englund, M.H. Asif, M. Willander, F. Elinder, Intracellular $\mathrm{K}^{+}$concentration decrease is not obligatory for apoptosis, J. Biol. Chem. 286 (2011) 39823-39828.

[140] M.H. Asif, B. Danielsson, M. Willander, ZnO nanostructure-based intracellular sensor, Sensors 15 (2015) 11787-11804.

[141] K. De Wael, D. Daems, G. Van Camp, L.J. Nagels, Use of potentiometric sensors to study (Bio)molecular interactions, Anal. Chem. 84 (2012) 4921-4927.

[142] E. Hamidi-Asl, D. Daems, K. De Wael, G. Van Camp, L.J. Nagels, Concentrationrelated response potentiometric titrations to study the interaction of small molecules with large biomolecules, Anal. Chem. 86 (2014) 12243-12249.

[143] D. Daems, G. Van Camp, M. Fernandez, Y. Guisez, E. Prinsen, L.J. Nagels, Use of potentiometric detection in (ultra) high performance liquid chromatography and modelling with adsorption/desorption binding kinetics, Anal. Chim. Acta 777 (2013) 25-31.

[144] D. Harris, J.G. Ummadi, A.R. Thurber, Y. Allau, C. Verba, F. Colwell, M.E. Torres, D. Koley, Real-time monitoring of calcification process by Sporosarcina pasteurii biofilm, Analyst 141 (2016) 2887-2895.

[145] S.K. Lee, W.F. Boron, M.D. Parker, Monitoring ion activities in and around cells using ion-selective liquid-membrane microelectrodes, Sensors 13 (2013) 984-1003.

[146] R. Toczylowska-Maminska, A. Lewenstam, K. Dolowy, Multielectrode biosensor system for time-resolved monitoring of ion transport across an epithelial cell layer, Anal. Chem. 86 (2014) 390-394. 
[147] M. Zajac, A. Lewenstam, K. Dolowy, Multi-electrode system for measurement of transmembrane ion-fluxes through living epithelial cells, Bioelectrochemistry 117 (2017) 65-73.

[148] E. Bakker, E. Pretsch, Nanoscale potentiometry, TrAC, Trends Anal. Chem. 27 (2008) 612-618.

[149] J.B. Hu, A. Stein, P. Bühlmann, A disposable planar paper-based potentiometric ion-sensing platform, Angew. Chem. Int. Ed. 55 (2016) 7544-7547.

[150] R. Cánovas, S. Padrell Sánchez, M. Parrilla, M. Cuartero, G.A. Crespo, Cytotoxicity study of ionophore-based membranes: toward on-body and in vivo ion sensing, ACS Sens. 4 (2019) 2524-2535.
[151] M. Pawlak, E. Bakker, Chemical modification of polymer ion-selective membrane electrode surfaces, Electroanalysis 26 (2014) 1121-1131.

[152] X.J. Jiang, P. Wang, R.N. Liang, W. Qin, Improving the biocompatibility of polymeric membrane potentiometric ion sensors by using a mussel-inspired polydopamine coating, Anal. Chem. 91 (2019) 6424-6429.

[153] T.J. Jiang, L.B. Qi, W. Qin, Improving the environmental compatibility of marine sensors by surface functionalization with graphene oxide, Anal. Chem. 91 (2019) 13268-13274.

[154] P.G. Boswell, P. Bühlmann, Fluorous bulk membranes for potentiometric sensors with wide selectivity ranges: observation of exceptionally strong ion pair formation, J. Am. Chem. Soc. 127 (2005) 8958-8959. 